\title{
Effect of Organic Manures and Biofertilizers on Growth, Yield and Quality Traits of Tomato (Solanum lycopersicum Mill.) cv. Roma
}

\author{
Vinod Kumar ${ }^{1}$, R.B. Ram ${ }^{1}$, Abhijeet Srivastava ${ }^{1 *}$, Raj Pandey ${ }^{2}$, Hari Baksh ${ }^{2}$, Himanshu \\ Singh $^{3}$ and Maneesh Kumar Singh ${ }^{4}$
}

${ }^{1}$ Department of Applied Plant Science (Horticulture), Babasaheb Bhimrao Ambedkar

University, Vidya-Vihar, Rae-Bareli Road, Lucknow - 226025 (U.P.), India

${ }^{2}$ Tilak Dhari Post Graduate College, Jaunpur (U.P.) India

${ }^{3}$ Krishi Vigyan Kendra, Jhansi-284003 (U.P.) India

${ }^{4}$ ICAR-ATARI, Kanpur (U.P.), India

*Corresponding author

\section{Keywords}

Organic manure,

Biofertilizer,

Growth, Yield,

Quality and Tomato crops

\section{Article Info}

Accepted:

10 February 2019

Available Online:

10 March 2019

\section{A B S T R A C T}

A field study was conducted at Horticulture research farm, Department of Applied Plant Science (Horticulture), Babasaheb Bhimrao Ambedkar University, Lucknow during Rabi season of 2014-15 to study the effect of organic manures and bio-fertilizers on growth, yield and quality traits of tomato cv. Roma. The seedlings were transplanted in last week of October with a spacing $60 \mathrm{~cm} \times 45 \mathrm{~cm}$. The experiment was laid out in Randomized Block Design with twelve treatments replicated thrice. Result indicated that the maximum height of the plant $(21.95,33.91$ and $45.15 \mathrm{~cm})$ was recorded at 30,60 and 90 DAT with $50 \% \mathrm{RDF}+50 \% \mathrm{VC}+\mathrm{PSB}$ application followed by 50\% RDF+ 50\% VC+ Azosporillum and minimum in control. The number of branches $(4.13,10.09$ and 16.03) was recorded at 30,60 and 90 DAT with the application of 50\% RDF+ 50\% VC+ Azosporillum, followed by $50 \% \mathrm{RDF}+50 \% \mathrm{VC}+\mathrm{PSB}$ and minimum in control. The number of days taken by plants for flowering was less under control (41.52). The maximum number of flowers, flower clusters and fruits/plant were 31.93, 9.09 and 18.00 respectively in 50\% RDF+ 50\% VC+ Azosporillum. Similarly maximum fruit weight $(70.94 \mathrm{gm})$ and fruit diameter (7.06 $\mathrm{cm}$ ) were also noticed with the application of $50 \% \mathrm{RDF}+50 \% \mathrm{VC}+$ Azosporillum which is significantly superior over control. Same trend was also noticed in yield per plant $(0.991$ $\mathrm{kg}$ ), per plot $(15.87 \mathrm{~kg})$ and per ha $(73.33 \mathrm{q})$ in the same treatment. The maximum titrable acidity 0.72 was in control among fruits of different treatments while minimum titrable acidity (0.56) was found in fruits of treatment received 50\% RDF+ 50\% FYM+ Azosporillum. The maximum TSS (5.400B) obtained from the fruits given $100 \%$ Vermicompost and minimum in control (3.650Brix). Highest vitamin $\mathrm{C}$ of fruits has been recorded in the $50 \% \mathrm{RDF}+50 \% \mathrm{VC}+$ Azosporillum (23.90\%) as compared to the control $(21.71 \%)$. 


\section{Introduction}

Tomato (Solanum lycopersicum Mill) $2 \mathrm{n}=24$, is one of the important vegetable crops which contain important minerals and vitamins. The tomato is an herbaceous annual to perennial prostate and sexually propagated crops of commercial importance. It produces a strong tap root which is very often damaged at the time of transplanting, consequently the lateral adventious roots develop and anchor the plants. On the basis of growth habit, it is of two types i.e. determinate and indeterminate. Botanically a tomato fruit is berry consisting of seed within fleshy pericarp develops from an ovary, tomato fruit are composed of flesh (pericarp wall and skin) and pulp, placenta and locular tissues. It is often called poor man's orange or wolf apple because of its high nutritive value. It has spread to most parts of the world in the 16th century. It is one of the most popular salad vegetables and taken with great relish. It is widely employed in cannery and made into soups, pickles, ketchup, sauces, juice etc. Cultural practices including the proper nutrition of vegetable crops play significant role in improving the yield as well as the quality traits (Vasnthakumar, 2003). It has been reported by early workers that majority of Indian soil are deficient in nitrogen often in phosphorus and sometimes in potash. These major nutrients, therefore, are applied in optimal doses for healthy production. Bio-fertilizer is a natural product carrying living microorganisms derived from the root or cultivated soil. So they don't have any ill effect on soil health and environment. A small dose of bio-fertilizer is sufficient to produce desirable results because each gram of carrier of bio-fertilizers contains at least 10 million viable cells of a specific strain. These beneficial effects of Azospirillum on plants are attributed mainly to an improvement in root development an increase in the rate of water and minerals uptake by roots, displacement of fungi and plant pathogenic bacteria and to a lesser extent, biological nitrogen fixation (Rao and Sankar, 2001). The effect of organic manures specially farm yard manure and vermicompost on vegetative growth, quality and shelf life tomato fruits has been well established. The ability of Azospirillum to produce plant growth regulatory substances along with N2 fixation stimulate plant growth and thereby productivity. All these factors combined together produce positive effects on crop yield especially for vegetables and cereals.

\section{Materials and Methods}

The present study was conducted at Horticulture Research Farm, Department of Applied Plant Science (Horticulture), Babasaheb Bhimrao Ambedkar University, Lucknow during Rabi season of 2014-15. The climatic condition of Lucknow is sub-tropical with three distinct seasons i.e., winter, summer and rainy. The variety of tomato "Roma" was selected for the study. The seed of cultivar was obtained from the IARI, New Delhi. Tomato was fertilized with recommended $(100 \%)$ doses and half of the recommended doses (50\%) of integrated sources of nutrients viz., NPK @ 100,120and $80 \mathrm{~kg} / \mathrm{ha}$. The seed were sown in nursery beds during last week of October and germination took place about week after. The seedlings were transplanted in first week of December at a spacing $60 \mathrm{~cm} \times 45 \mathrm{~cm}$ in field plots. The branches of all four tagged plants were counted which was started after 30 days after transplanting.

The experiment was planned with treatments namely T1 (Control), T2 (RDF 100\%), T3 (Vermicompost $100 \%)$, T4 (75\% RDF + 25\% $\mathrm{VC}+\mathrm{PSB}), \mathrm{T} 5(50 \% \mathrm{RDF}+50 \% \mathrm{VC}+$ $\mathrm{PSB}), \quad \mathrm{T} 6 \quad(75 \% \mathrm{RDF}+25 \% \mathrm{VC}+$ Azospirillum), T7 (50\% RDF + 50\% VC + Azospirillum), T8 (FYM 100\%), T9 
$(75 \% \mathrm{RDF}+25 \% \mathrm{FYM}+\mathrm{PSB}), \mathrm{T} 10(50 \%$ $\mathrm{RDF}+50 \% \mathrm{FYM}+\mathrm{PSB}), \mathrm{T} 11(75 \% \mathrm{RDF}+$ 25\% FYM + Azospirillum), T12 (50\% RDF + $50 \%$ FYM + Azospirillum). All the treatments were replicated thrice. Urea was applied in two splits before planting and at flowering stages while the full dose of phosphorus and potash was given before planting. Seedling treated with Phosphorus Solubilising Bacteria (PSB) and Azosporillum solutions were made by dissolving $50 \mathrm{ml}$ inoculums in 20 liters of water and transplanted. The experiment was laid out in Randomized Block Design with twelve treatments and three replications. Five fruit were randomly harvested from each treatment having uniform shape and size. Observations on vegetative growth parameters were recorded at 30 days interval.

The matured fruits were harvested from selected plant and weighted accordingly after fruit weighing the average fruit weight was multiplied by total number of fruit per plant to get fruit yield per plant. Three chemical traits acidity, TSS and ascorbic acids were also studied by using mature tomato fruits.

\section{Titratable acidity (\%)}

Titratable acidity was determined by titration in terms of citric acid with $\mathrm{NaOH} 0.1 \mathrm{~N}$ where $10 \mathrm{ml}$ of the sample was taken and dissolved to make up the volume to $100 \mathrm{ml}$ with water and filtered through muslin cloth. $10 \mathrm{ml}$ of this aliquot was titrated against $0.1 \mathrm{~N}$ $\mathrm{NaOH}$ using few drop of $1 \%$ phenolphthalein indicator till the pink color appears.

\section{Total soluble solids (0Brix)}

Pulp from three fruits was randomly taken from composite sample and crushed for extracting the juice. TSS was estimated with the help of a hand refractometer (0-32 range) and expressed as 0Brix.

\section{Ascorbic acid (mg/100 g)}

Ascorbic Acid was determined by using 2, 6dichlorophenol- indophenols through visual titration method $10 \mathrm{~g}$ sample was taken and volume was made up to $100 \mathrm{ml}$ with $3 \%$ metaphosphoric acid and filtered with filter paper $10 \mathrm{ml}$ of this aliquot extract of the sample was titrated with the standard dye to the pink end-point which persisted for 15 seconds.

\section{Results and Discussion}

The data (Table 1) revealed that plants in treatment T5 have maximum height $(21.95 \mathrm{~cm}), \quad(33.91 \mathrm{~cm})$ and $(45.15 \mathrm{~cm})$ as compared to control $(18.10 \mathrm{~cm}),(27.17 \mathrm{~cm})$ and $(36.17 \mathrm{~cm})$.Maximum number of branches (4.13), (10.09) and (16.03) were recorded from $\mathrm{T} 7$. While the minimum number of branch (2.94), (6.02) and (10.16) per plant was recorded in T1 treatment at 30 DAT, 60 DAT and 90 DAT. The minimum number of days (41.52) for blooming was observed in T1.The data presented in Table 2 revealed that the number of flowers/plant in T7(31.93), T5 (31.03) and T12 (30.09) which were significant increase over the T1 (22.17). The maximum numbers of flower clusters/plant was obtained in T7 (9.09). This increase may be due to application of Azospirillum which increased flower clusters/plant significantly over the T1 (5.19). Similar findings were obtained by Singh, S.R. 2004 and Meena et al., (2014). Treatment T7 has produced maximum (18.00) number of fruits/plant followed by T5 (17.17) which were significantly superior over the T1 (12.11). The maximum fruit weight (70.94 gm) was obtained in T7 as compared to the control (55.10 gm). The maximum fruit diameter was noticed in T7 $(7.06 \mathrm{~cm})$ followed by T5 $(6.95$ $\mathrm{cm})$ and T12 $(6.57 \mathrm{~cm})$ which was significantly superior over the control (3.20). 
Table.1 Effect of organic manures and bio-fertilizers on plant height/plant and number of branches and flowering of tomato plant $c v$. Roma

\begin{tabular}{|c|c|c|c|c|c|c|c|c|c|}
\hline \multirow[t]{2}{*}{ Treatments } & \multicolumn{3}{|c|}{ Plant heights (DAT) } & \multicolumn{3}{|c|}{$\begin{array}{c}\text { Branches (DAT) } \\
\text { (DAT) }\end{array}$} & \multicolumn{3}{|c|}{ Flowering of tomato plant } \\
\hline & 30 & 60 & $\begin{array}{l}90 \\
\text { Flowe }\end{array}$ & 30 & 60 & 90 & $1^{\text {st }}$ & $\begin{array}{c}50 \% \\
\text { Flowering }\end{array}$ & $\begin{array}{r}\text { Days to } \\
\text { fruits set }\end{array}$ \\
\hline $\mathrm{T}_{1}$ & 18.10 & 27.17 & 36.17 & 2.94 & 6.02 & 10.16 & 41.52 & 52.56 & 69.49 \\
\hline$T_{2}$ & 19.81 & 32.11 & 42.21 & 3.24 & 8.64 & 12.96 & 41.62 & 52.69 & 69.74 \\
\hline $\mathrm{T}_{3}$ & 19.12 & 32.02 & 43.08 & 3.15 & 8.30 & 12.36 & 42.08 & 53.11 & 70.17 \\
\hline $\mathrm{T}_{4}$ & 20.24 & 33.36 & 44.35 & 3.48 & 8.34 & 13.95 & 42.98 & 54.01 & 71.02 \\
\hline$T_{5}$ & 21.95 & 33.91 & 45.15 & 3.99 & 9.92 & 15.42 & 41.94 & 52.94 & 69.99 \\
\hline $\mathrm{T}_{6}$ & 20.16 & 32.87 & 43.84 & 3.72 & 9.39 & 14.41 & 43.17 & 54.43 & 71.20 \\
\hline $\mathrm{T}_{7}$ & 21.39 & 33.55 & 44.92 & 4.13 & 10.09 & 16.03 & 41.82 & 52.88 & 69.91 \\
\hline $\mathrm{T}_{8}$ & 19.16 & 31.26 & 43.18 & 3.06 & 8.18 & 11.94 & 42.20 & 53.19 & 70.21 \\
\hline $\mathrm{T}_{9}$ & 20.23 & 33.02 & 44.13 & 3.36 & 8.79 & 13.13 & 42.52 & 53.54 & 70.66 \\
\hline $\mathrm{T}_{10}$ & 21.37 & 33.50 & 44.73 & 3.85 & 9.55 & 14.76 & 43.13 & 53.80 & 71.18 \\
\hline $\mathrm{T}_{11}$ & 20.11 & 32.19 & 43.69 & 3.62 & 9.15 & 14.17 & 43.26 & 54.30 & 71.35 \\
\hline $\mathrm{T}_{12}$ & 21.27 & 33.43 & 44.50 & 3.95 & 9.73 & 15.05 & 43.71 & 54.75 & 71.81 \\
\hline S.E. Diff. & 0.093 & 0.078 & 0.105 & 0.063 & 0.571 & 0.066 & 0.025 & 0.127 & 0.022 \\
\hline C.D.at $5 \%$ & 0.031 & 0.027 & 0.036 & 0.021 & 0.193 & 0.022 & 0.073 & 0.375 & 0.066 \\
\hline
\end{tabular}


Table.2 Effect of organic manures and bio-fertilizers on number of flowers/plant, number of cluster/plant and number of fruits/plant, fruit diameter, fruit weight, fruit yield/plant, yield/plot and yield/ha, acidity, TSS and vitamin C of tomato fruits $c v$. Roma

\begin{tabular}{|c|c|c|c|c|c|c|c|c|c|c|c|}
\hline Treatments & $\begin{array}{c}\text { No. of } \\
\text { flowers/ } \\
\text { plant }\end{array}$ & $\begin{array}{c}\text { No. of } \\
\text { cluster/ } \\
\text { plant }\end{array}$ & $\begin{array}{c}\text { No. of } \\
\text { fruits/ } \\
\text { plant }\end{array}$ & $\begin{array}{c}\text { Fruit } \\
\text { diameter } \\
(\mathrm{cm})\end{array}$ & $\begin{array}{c}\text { Fruit } \\
\text { weight } \\
\text { (g) }\end{array}$ & $\begin{array}{c}\text { Fruit } \\
\text { yield/ } \\
\text { plant (kg.) }\end{array}$ & $\begin{array}{c}\text { Fruit } \\
\text { yield/plot } \\
\text { (kg.) }\end{array}$ & $\begin{array}{c}\text { Fruit } \\
\text { yield/ha } \\
\text { (q.) }\end{array}$ & $\begin{array}{c}\text { Acidity } \\
\%\end{array}$ & $\underset{ }{\text { T.S.S. }}$ & $\begin{array}{c}\text { Vitamin } \\
\text { C mg/100 } \\
\text { ml }\end{array}$ \\
\hline$T_{1}$ & 22.17 & 5.19 & 12.11 & 3.20 & 55.13 & 0.441 & 7.15 & 33.01 & 0.74 & 3.65 & 21.71 \\
\hline $\mathrm{T}_{2}$ & 25.02 & 6.11 & 14.05 & 4.37 & 57.09 & 0.563 & 8.92 & 41.29 & 0.67 & 3.76 & 21.83 \\
\hline $\mathrm{T}_{3}$ & 26.91 & 7.85 & 13.86 & 4.96 & 59.85 & 0.588 & 9.42 & 43.61 & 0.52 & 5.40 & 22.03 \\
\hline $\mathrm{T}_{4}$ & 28.27 & 8.05 & 15.13 & 5.50 & 63.24 & 0.701 & 11.24 & 51.89 & 0.61 & 4.40 & 22.40 \\
\hline $\mathrm{T}_{5}$ & 31.04 & 8.95 & 17.17 & 6.95 & 68.92 & 0.906 & 14.49 & 70.08 & 0.71 & 3.96 & 23.53 \\
\hline $\mathrm{T}_{6}$ & 29.40 & 8.70 & 15.96 & 6.10 & 63.57 & 0.781 & 12.46 & 57.68 & 0.57 & 4.71 & 22.77 \\
\hline $\mathrm{T}_{7}$ & 31.93 & 9.09 & 18.00 & 7.06 & 70.94 & 0.991 & 15.87 & 73.33 & 0.70 & 4.17 & 23.90 \\
\hline $\mathrm{T}_{8}$ & 25.16 & 6.85 & 13.19 & 4.35 & 60.19 & 0.552 & 8.83 & 40.78 & 0.55 & 5.19 & 21.95 \\
\hline $\mathrm{T}_{0}$ & 27.22 & 7.27 & 14.38 & 5.11 & 62.95 & 0.653 & 10.46 & 48.28 & 0.64 & 4.32 & 22.18 \\
\hline$T_{10}$ & 29.70 & 8.41 & 15.74 & 6.37 & 66.19 & 0.820 & 13.12 & 60.64 & 0.57 & 4.95 & 23.02 \\
\hline $\mathrm{T}_{11}$ & 29.04 & 8.14 & 15.50 & 5.85 & 64.47 & 0.737 & 11.79 & 54.58 & 0.60 & 4.50 & 22.52 \\
\hline$T_{12}$ & 30.09 & 8.90 & 16.93 & 6.61 & 67.93 & 0.879 & 14.09 & 65.09 & 0.56 & 5.07 & 23.19 \\
\hline S.E. Diff. & 0.034 & 0.047 & 0.196 & 0.022 & 0.486 & 0.003 & 0.010 & 0.866 & 0.009 & 0.019 & 0.022 \\
\hline C.D. at $5 \%$ & 0.100 & 0.138 & 0.579 & 0.065 & 1.435 & 0.008 & 0.029 & 2.556 & 0.026 & 0.057 & 0.065 \\
\hline
\end{tabular}


This increase in fruits weight mass was higher in $50 \% \mathrm{RDF}+50 \% \mathrm{VC}+$ Azospirillum by virtue of varietal characteristics, which has promoted the growth of all vegetative parts and consequently more food material synthesized for such plants with higher fruits weight obtained. Similar results have been reported by Meena et al., (2014) and Chaudhary et al., (2005). The treatment $\mathrm{T} 7$ and $\mathrm{T}_{5}$ has given the highest yield $(0.991 \mathrm{~kg}$ and 0.906 $\mathrm{kg}$ ). /plant respectively which was significantly superior over control $(0.441 \mathrm{~kg})$. Similar results have also been repeated by Meena et al., (2014) and Chaudhary et al., (2005).

It has been noticed that the $\mathrm{T} 7$ treatment has contributed highest yield/plot $(15.87 \mathrm{~kg})$ followed T5 $(14.99 \mathrm{~kg})$. However, in this case these characters have higher values in the treatment of $50 \% \mathrm{RDF}+50 \% \mathrm{VC}+$ Azospirillum in all replications. Treatment $\mathrm{T} 7$ have highest fruit yield/ha (73.33 q.) followed by T5 (70.08 q.) and in $\mathrm{T} 1$ it was recorded 33.01 q. The maximum tritable acidity $(0.72)$ was in the fruits obtained from treatment $\mathrm{T} 1$ and minimum in fruits of the treatment $\mathrm{T} 12$ (0.56). The maximum T.S.S. (5.400Brix) obtained from fruits of $\mathrm{T} 3$ followed by $\mathrm{T} 8$ (5.190Brix) and it was $3.650 \mathrm{Brix}$ in $\mathrm{T}_{1}$. It was evident that the application of Vermicompost increases T.S.S. considerably. Such results are in the conformity with Sendur et al., (1998) and Chandrasekhar (2003). Highest vitamin C of fruits has been recorded in the T7 $(23.90 \%)$ followed by T5 $(23.53 \%)$ as compared to the T1 $(21.71 \%)$.The increase in these vegetative growth and yield may be due to inorganic, organic and bio-fertilizers (Phosphorus solublizing bacteria and Azosporillum) sources of nutrients. The addition of bio-fertilizers might have helped in $\mathrm{N}$-fixation and its quick release for plants absorption. The results are in conformity with Chaudhary, et al., (2005), Meena et al., (2014), Sendur et al., (1998) and Wange and Kale (2004).

\section{References}

Chandrasekhar, B.S. (2003). Studies on mineral phosphate solubilizing fungi from vertisols of Northern Karnataka and other Bio-fertilizer potential. Ph.D. Thesis, Univ. Agric. Sci., Dharwad, Karnataka, India.

Chaudhary, M.R., Talukdar, N.C. and Saikia, A. (2005). Effect of Integrated Nutrient Management on growth and productivity of brinjal. Research on crops.6: (3) 551554.

Meena, R.K., Kumar, S., Maji. S., Kumar. D. and Kumar, M (2014). Effect of organic manures and bio-fertilizers on growth, flowering, yield and quality of tomato cv. Pusa Sheetal. International Journal of Agricultural Sciences Vol.10(1):329332.

Rao, T.S.S. and Sankar, C.R. (2001). Effect of organic manures on growth and yield of brinjal. South Indian Horticulture; 49 (special): 288-291.

Sendur, K.S., Natarajan, S. and Thamburaj, S. (1998). Effect of organic and inorganic fertilizers on growth, yield and quality of tomato. South Indian Hort. 46(3): 203205

Singh, S.R. (2004). Effect of organic farming system on yield and quality of brinjal (Solanum melongena L.) var. Pusa Purple Cluster under mid hill conditions of Himachal Pradesh. Haryana Journal of horticultural Sciences; 33: 3/4, 265-266.

Vasnthakumar, S.K. (2003). Studies on beneficial endorhizosphere bacteria. M.Sc. (Ag.) Thesis University of Agric. Sci. Dharwad Karnataka India.

Wange, S.S. and Kale, R.H. (2004). Effect of bio-fertilizers under graded nitrogen levels on brinjal crop. J. Soils and Crops, 14(1): 9-11.

\section{How to cite this article:}

Vinod Kumar, R.B. Ram, Abhijeet Srivastava, Raj Pandey, Hari Baksh Himanshu Singh and Maneesh Kumar Singh. 2019. Effect of Organic Manures and Biofertilizers on Growth, yield and Quality Traits of Tomato (Solanum lycopersicum Mill.) cv. Roma. Int.J.Curr.Microbiol.App.Sci. 8(03): 994-999. doi: https://doi.org/10.20546/ijcmas.2019.803.120 